\title{
Production and Characterization of a Cytotoxic
}

\section{Monoclonal Antibody Reacting with Rat Islet Cells}

\author{
M. A. Crump, R. Scearce, M. Dobersen, W. Kortz, and G. S. Eisenbarth, \\ Departments of Medicine and Surgery, Duke University Medical Center, \\ Durham, North Carolina 27710; The National Dental Institute of the \\ National Institutes of Health, Bethesda, Maryland 20014
}

A BSTRACT We have produced a murine monoclonal antibody (F43 A1D2) that binds to the cell surface of both rat islet tumor cells (RINm clone $5 \mathrm{~F}$ and RINm clone 14B) and normal rat islet cells. This antibody is cytotoxic in the presence of complement for RIN tumor cells as well as A, B, and D pancreatic polypeptide rat islet cells. Antibody AID2 does not bind to rat thymus cells, pancreatic acinar cells, or fibroblasts. Antigen A1D2 (termed ICSAn-1 [islet cell surface antigen 1]) is a trypsin-sensitive glycoprotein with a molecular mass of $\sim 24,000$ daltons. In addition to purification of its islet cell antigen, antibody A1D2 can be used to identify and isolate living islet cells from pancreatic digests.

\section{INTRODUCTION}

Cell surface membranes express two general classes of antigenic determinants. One class includes antigens common to all cells of a particular organism, while the other is specific for given cell types, hence "differentiation antigens". In some patients with type I diabetes mellitus, circulating antibodies are detected that bind to the cell surface of viable islet cells (1) and are cytotoxic to cloned rat islet cells (2). Thus, islet cell surface antigens may be important targets of the autoimmune phenomenon in type I diabetes mellitus.

Studies defining the cell surface antigens reacting with antiislet antibodies have been limited by the small quantities of antibody available. With the introduction by Kohler and Milstein (3) of monoclonal antibody techniques, the investigation of cell surface antigens has been greatly simplified (4). Using these techniques we have developed a monoclonal antibody (F43 AlD2)

Address reprint requests to Dr. G. S. Eisenbarth. His present address is Joslin Diabetes Center, Research Division, Boston, MA 02215.

Received for publication 8 December 1981 and in revised form 1 April 1982. that binds to a surface differentiation antigen of islet cels. In this communication we define the binding specificities of this monoclonal antibody, the antigen with which it reacts, and the functional properties of the antibody.

\section{METHODS}

Isolation and preparation of cells for assay. Cell lines were grown at $35^{\circ} \mathrm{C}$ in RPMI 1640 medium supplemented with $10 \%$ heat-inactivated $\left(56^{\circ} \mathrm{C}\right.$ for $30 \mathrm{~min}$ ) bovine serum. RINm clone $5 \mathrm{~F}$ and RINm clone $14 \mathrm{~B}$ cells were supplied by Drs. A. Gazdar, H. Oie, and W. Chick (5). Both cell lines were derived from the RISL transplantable rat insulinoma. RINm clone $5 \mathrm{~F}$ and RINm clone $14 \mathrm{~B}$ cells synthesize insulin and somatostatin, respectively. GH3 cells derived from a rat pituitary tumor were obtained from the Salk Cell Distribution Center. Fibroblasts were obtained from trypsin-dissociated skin of NEDH rats, the strain of rats that gave rise to the RISL insulinoma.

Normal islet cells were isolated by standard procedures (6). Briefly, pancreata from neonatal Sprague-Dawley rats were minced with scissors and collagenase digested. Separation of islet cells was achieved by a discontinuous Ficoll gradient (6). Thymus cells were obtained by mincing rat thymus from either neonatal or adult Sprague-Dawley rats with a fine scissor.

Generation of monoclonal antibody F43 A1D2. The general methodology for the production of murine monoclonal antibodies to rat RIN cells has been described (7). Antibody containing ascites and diluted antibody were stored at $-20^{\circ} \mathrm{C}$.

$I^{125}$-Protein A radioassay. The basic assay used has been described previously (7). The assay depends on the binding of staphylococcal protein A to the Fc region of certain immunoglobulins, including antibody A1D2.

Indirect immunofluorescence. RINm clone $5 \mathrm{~F}$ and RINm clone 14B cells were removed from cultured monolayers by incubation with phosphate-buffered saline $(\mathrm{PBS})^{1}$ without calcium and magnesium. After incubation for $10 \mathrm{~min}$ with PBS, flasks were vigorously agitated and the cell suspension removed and centrifuged for $5 \mathrm{~min}$ at $300 \mathrm{~g}$. The cell pellet was resuspended in $1 \%$ PBS albumin. Cells $\left(10^{5} / 50 \mu \mathrm{l}\right)$ were

${ }^{1}$ Abbreviation used in this paper: PBS, phosphate-buffered saline. 
then incubated with $50 \mu \mathrm{l}$ of anti-mouse antibody conjugated with fluorescein isothiocyanate diluted 1:10 in 1\% PBS albumin, washed, placed on a slide, and studied with a Leitz diavert microscope equipped for epifluorescence (E. Leitz, Inc., Rockleigh, NJ). In addition, cells lysed by antibody A1D2 in the presence of complement could be identified by uptake of eithidium bromide using a rhodamine fluorescent filter. The type of islet cell lysed is identified by incubation with antibodies to either insulin, glucagon, somatostatin, or pancreatic polypeptide followed by incubation with fluorescein-coupled antiantibody. The technique is detailed in a recent publication (8).

${ }^{51} \mathrm{Cr}$ cytotoxicity assay. A chromium release assay was used to assess the ability of antibody A1D2 to kill RINm5F cells in the presence of rabbit complement. The assay technique has been described (2). Ascites from monoclonal antibodies A1D2, 6B2 (positive control), and P3X63 (negative control) were diluted 1:100 in RPMI 1640 medium.

Antigen isolation and characterization. RINm clone $5 \mathrm{~F}$ cells were labeled by incubating overnight with $\left[{ }^{3} \mathrm{H}\right]$ leucine, in leucine-free culture medium. Labeled cells, after extensive washing, were extracted with $0.3 \%$ Triton in PBS for $5 \mathrm{~min}$ at $4^{\circ} \mathrm{C}$, the extract centrifuged at $10,000 \mathrm{~g}$ for $15 \mathrm{~min}$ at $4^{\circ} \mathrm{C}$ and the supernatant containing $3.8 \times 10^{6} \mathrm{cpm}$ was applied to a lentil lectin Sepharose 4B column (Pharmacia Fine Chemicals, Piscataway, NJ). The column was washed extensively with PBS containing $0.3 \%$ Triton and then bound radioactivity was eluted with $160 \mathrm{mM}$ mannose in $0.3 \%$ Triton in PBS. The peak of eluted counts was then applied (3 $\times 10^{4} \mathrm{cpm}$ for each column) to an antibody A1D2 affinity column and to a control antibody $3 \mathrm{Al}$ column. These columns were prepared by binding the respective monoclonal antibodies to protein A Sepharose columns (Pharmacia Fine Chemicals) with washing to remove unbound antibody. The antibody affinity columns after incubation with the lentil lectin purified extract were washed extensively with PBS containing $0.3 \%$ Triton and then bound radioactivity was eluted with $1 \mathrm{M}$ propionic acid. The peak of eluted counts from both columns were boiled in $10 \%$ SDS containing mercaptoethanol and then electrophoresed on $10 \%$ polyacrylamide gels. The molecular weight of antigen A1D2 was determined by comparison with the migration of known molecular weight standards on a companion gel.

Islet cell isolation using antibody A1D2. Pancreata were removed from neonatal Sprague-Dawley rats, cleaned of spleen and bowel remnants, and washed two times in cold Hanks' solution. Tissue was then minced with two scalpels and washed two times with cold Hanks' solution. Worthington type II collagenase (Worthington Biochemical Corp., Freehold, NJ) $40 \mathrm{mg} / 4 \mathrm{ml}$ Hanks' solution was added and tissue was shaken at $37^{\circ} \mathrm{C}$ for $10 \mathrm{~min}$ until all chunks were dissociated. The cells were then incubated with a 1:50 dilution of antibody A1D2 in RPMI $2 \%$ with fetal calf serum and incubated at $4^{\circ} \mathrm{C}$ for $30 \mathrm{~min}$. Bacterial petri dishes (Falcon 1001, Falcon Labware, Div. of Becton, Dickinson \& Co., Oxnard, CA) were incubated the day before with 30 $\mu \mathrm{l} / 3 \mathrm{ml}$ affinity purified goat anti-mouse antibody (TAGO code 4150) in PBS $0.05 \% \mathrm{Na}$ Azide. Immediately prior to use the plate was washed five times with PBS.

Following incubation with antibody A1D2 the pancreatic digest was suspended in $3 \mathrm{ml}$ RPMI medium containing $2 \%$ fetal calf serum and added to the petri dish with adsorbed anti-mouse antibody and incubated at $4^{\circ} \mathrm{C}$ for $30 \mathrm{~min}$. Islet cells rapidly adhered to the plate and after $30 \mathrm{~min}$ acinar cells and fibroblasts were removed by rinsing the plate with medium.

\section{RESULTS}

Monoclonal antibody F43 A1D2 resulted from the fusion of the P3X63 murine myeloma cell line with splenic lymphocytes of a Balb/c mouse immunized with whole RINm5F cells (7). The resulting cell line has been cloned by limiting dilution and large amounts of antibody produced by growing the cell line as an ascites tumor in Balb/c mice.

Serial dilutions of antibody A1D2 were incubated with RINm clone $5 \mathrm{~F}$ cells of fibroblasts and the binding of antibody detected with ${ }^{125} \mathrm{I}$-protein A. Antibody A1D2 bound to RINm clone 5F cells but not fibroblasts (Fig. 1). The binding of antibody A1D2 to RIN cell lines is independent of the cells ability to synthesize insulin. The RIN clone 14B cell line, which synthesizes somatostatin, also reacts with antibody A1D2 (Fig. 2). Also shown in Fig. 2 is the lack of reaction of antibody A1D2 with GH3 cells, a rat pituitary cell line.

Indirect immunofluorescence. Having determined that antibody A1D2 bound specifically to the rat islet cell tumor line, its binding to normal islet cells was studied. A 1:100 dilution of antibody A1D2 was incubated with living normal rat islet cells followed by incubation with fluorescein isothiocyanate-conjugated anti-mouse antibody. Islet cells showed rim fluorescence, indicative of the binding of antibody A1D2. When islet cells were not isolated and a pancreatic collagenase digest was reacted with antibody A1D2 a highly contrasting pattern of antibody binding was apparent on the different cell types present in the digest. The cells of greater size and number, which con-

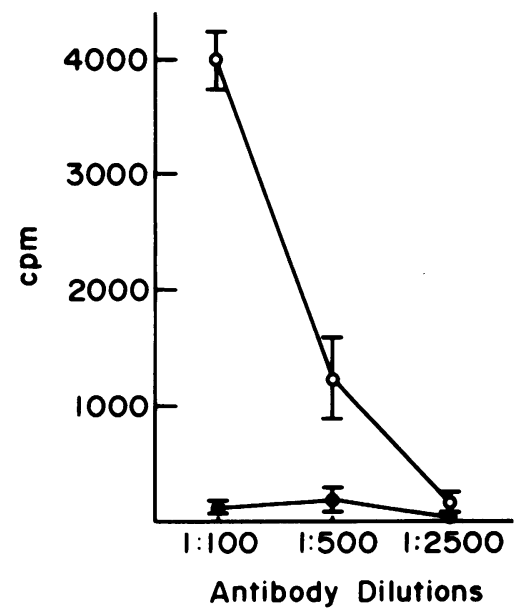

Figure $1{ }^{125}$ I-Protein A radioassay. Results expressed as the mean \pm SEM of counts bound in the presence of diluted antibody A1D2 minus binding with negative control ascites P3X63 for binding to RINm clone 5F cells $(O)$ and fibroblasts $(\bullet)$. 


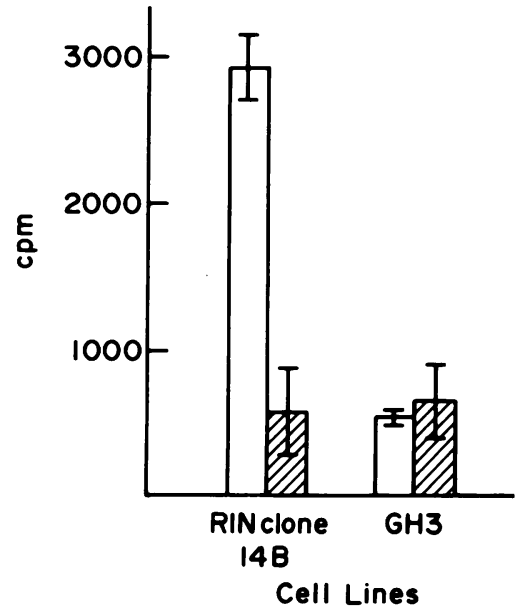

FIGURE $2{ }^{125}$ I-Protein A radioassay. Mean \pm SEM of counts bound after incubation of RINml4B or GH3 cells with a

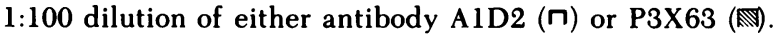

tained large inclusions under phase microscopy (acinar cells), showed no fluorescence. Islet cells displayed rim fluorescence (Fig. 3). Incubation of isolated thymus cells with antibody A1D2 and fluorescein isothiocyanate-conjugated anti-mouse antibody resulted in no cellular staining (data not shown).

Cytotoxicity. The amount of ${ }^{51} \mathrm{Cr}$ released by RINm cells can be used to quantitate antibody-dependent cytotoxicity in the presence of rabbit complement. Monoclonal antibody 6B2 (a known cytotoxic antibody) was used as a positive control and reflected variability in the total ${ }^{51} \mathrm{Cr}$ release in experiments performed with different cultures of RINm $5 \mathrm{~F}$ cells. Table I gives mean counts/minute \pm standard error of the mean of three experiments. In experiment I antibody A1D2 released 13,786 $\pm 1,562 \mathrm{cpm}$ compared with $15,635 \pm 1,097 \mathrm{cpm}$ for antibody $6 \mathrm{~B} 2$ (the positive control), and $2,228 \pm 265 \mathrm{cpm}$ for the negative antibody control, P3X63. Three separate experiments are shown and illustrate the range of variability of the ${ }^{51} \mathrm{Cr}$ release with this assay. For all experiments, antibody $6 \mathrm{~B} 2$ released more ${ }^{51} \mathrm{Cr}$ than antibody AID2.

In the presence of rabbit complement antibody A1D2 is also cytotoxic to normal rat islet cells. Lysed cells are identified by their uptake of ethidium bromide into the nucleus (orange nuclear fluorescence with "rhodamine filter") and the type of islet cell by its reaction with antibody to either insulin, glucagon, somatostatin, or pancreatic polypeptide followed by fluorescein-coupled antiantibody (green cytoplasmic fluorescence with "fluorescein filters"). As shown in Fig. 4, antibody A1D2 is cytotoxic to insulin containing cells (A to C) and glucagon containing cells (D through
F). Panels A and D show cells lysed by antibody A1D2 with nuclear fluorescence due to ethidium bromide. Fig. 4B shows the same field of cells as Fig. 4A but utilizing the fluorescein filter and thus detecting cells containing insulin (reaction with antiinsulin antibody and fluorescein isothiocyanate-coupled antiantibody resulting in green fluorescence). Finally, Fig. $4 \mathrm{C}$ is a double-exposure photograph of the same field of cells exposing the photographic film with both the fluorescein and rhodamine filters. Fig. $4 \mathrm{E}$ is a fluorescence photomicrograph utilizing the fluorescein filter for cells reacting with antiglucagon antibody, and Fig. $4 \mathrm{~F}$ a double-exposure photomicrograph of the cells taking up ethidium bromide (A1D2 cytotoxicity) and reacting with antiglucagon antibody. Antibody A1D2 is cytotoxic to insulin and glucagon containing cells (Fig. 4). Greater than $90 \%$ of beta cells were always lysed whereas in some fields a significant number of other islet cells survived incubation with antibody A1D2 and complement (though the majority were lysed). Antibody A1D2 is also cytotoxic to somatostatin and pancreatic polypeptide containing cells (data not shown). In Fig. 4, a monolayer of fibroblasts is barely discernable. These cells are not lysed by antibody A1D2 as one would predict from the radioassay studies. The absence of cytotoxicity of antibody A1D2 for fibroblasts is also illustrated in Fig. 5 (left panel) as contrasted with the cytotoxicity of unabsorbed human serum for rat fibroblasts (Fig. 5, right panel).

Islet cell isolation. The specificity of binding of antibody A1D2 to islet cells, as opposed to acinar and fibroblasts, suggested that the antibody would be useful for purifying islets from unfractionated pancreatic digests. As described in the Methods a collagenase digest of neonatal rat pancreas was incubated with antibody A1D2. The digest contained $695 \mathrm{mU}$ of insulin/ mg protein. Cells reacting with antibody A1D2 were then bound to a petri dish using adsorbed anti-mouse antibody. The bound cells contained $4,700 \mathrm{mU}$ insulin $/ \mathrm{mg}$ as compared with the nonbound $320 \mathrm{mU}$ insulin/mg protein, an $\sim 15$-fold difference in insulin content. Incubation of the islet digest with control monoclonal antibody P3X63 rather than antibody AlD2 resulted in no islet binding to the plates.

Antigen isolation and characterization. The stability of antibody A1D2 to organic solvents and trypsin was studied using indirect immunofluorescence. Antibody A1D2 binding was unaffected by incubation of RIN cells with $3 \%$ formaldehyde but incubation of formaldehyde-fixed RINm $5 \mathrm{~F}$ cells with trypsin or chloroform/methanol $(2: 1, \mathrm{vol} / \mathrm{vol})$ resulted in loss of antibody A1D2 binding. Chloroform alone had no effect on the fluorescence pattern (data not shown). Antigenic activity could not, however, be recovered from 


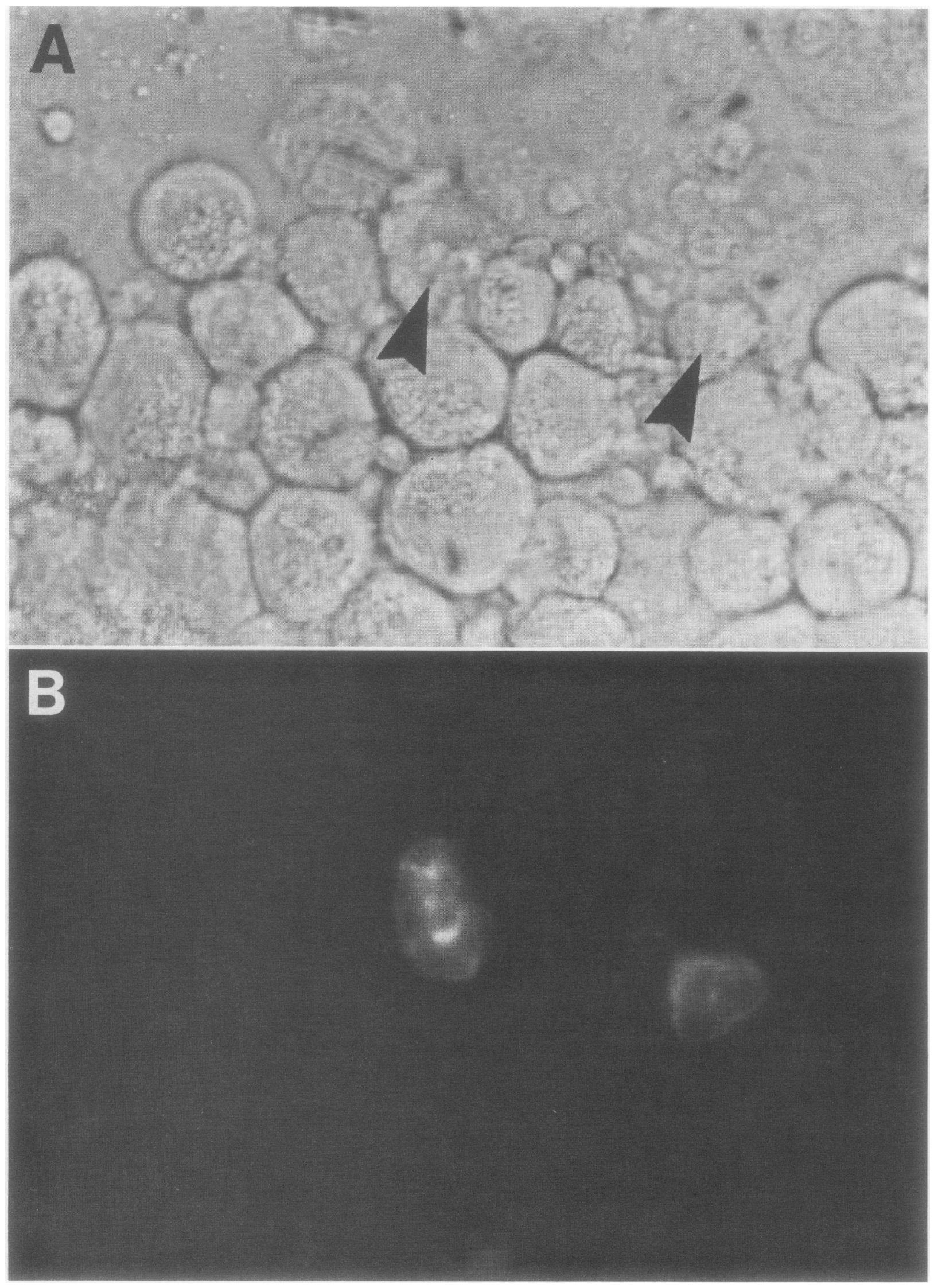


TABLE I

Cytotoxic Activity of Antibody A1D2 Using RINm5F Target Cells

\begin{tabular}{|c|c|c|}
\hline Experiment & Antibody & ${ }^{31} \mathrm{Cr}$ Release \\
\hline \multirow[t]{5}{*}{$\mathbf{I}$} & A1D2 & $13,786 \pm 1,562^{\circ}$ \\
\hline & P3X63 & $2,228 \pm 265$ \\
\hline & $6 \mathrm{~B} 2$ & $15,635 \pm 1,067$ \\
\hline & None & $1,729 \pm 55$ \\
\hline & None $+0.3 \%$ Triton $\ddagger$ & $18,793 \pm 1,459$ \\
\hline \multirow[t]{5}{*}{ II } & AlD2 & $14,271 \pm 973$ \\
\hline & P3X63 & $1,743 \pm 81$ \\
\hline & $6 \mathrm{~B} 2$ & $24,077 \pm 1,285$ \\
\hline & None & $1,655 \pm 160$ \\
\hline & None $+0.3 \%$ Triton & $20,203 \pm 1,140$ \\
\hline \multirow[t]{5}{*}{ III } & A1D2 & $6,591 \pm 1,644$ \\
\hline & P3X63 & $1,114 \pm 469$ \\
\hline & $6 \mathrm{~B} 2$ & $9,347 \pm 810$ \\
\hline & None & $2,763 \pm 293$ \\
\hline & None $+0.3 \%$ Triton & $15,767 \pm 987$ \\
\hline
\end{tabular}

- Data represent mean \pm SEM of three determinations. All incubations were in the presence of rabbit complement. There was no significant cytotoxicity of antibodies in the absence of complement (data not shown).

† $0.3 \%$ Triton X-100 was used to lyse all of the cells for determination of total ${ }^{51} \mathrm{Cr}$ incorporation.

a chloroform/methanol extract of the RINm5F cells (as can be accomplished with the glycolipid antigen A2B5, data not shown). This suggests that chloroform/ methanol denatured the antigen. The sensitivity to trypsin and the inability to recover antigenic activity in lipid solvents suggested that antigen A1D2 was a protein. We, therefore, tritium-labeled RINm clone $5 \mathrm{~F}$ cells with leucine and extracted labeled antigen with $0.3 \%$ Triton in PBS. Isolation and purification of the antigen was accomplished by affinity chromatography on a lentil lectin column eluted with mannose followed by an antibody A1D2 affinity column eluted with acid. Polyacrylamide gel electrophoresis of the affinity purified antigen revealed a single peak (distinct from the origin and front of the gel) with a molecular mass of 24,000 daltons (Fig. 6). Using a control antibody affinity column (monoclonal antibody [3Al] that does not react with RIN cells) peaks of radioactivity were present only at the origin and front of the gel (data not shown). In addition, the immunoprecipitate of ${ }^{125}$ I-labeled cell surface membranes of RINm5F cells (using antibody A1D2 and staphylococcal protein A) electrophoresed on a $10 \%$ polyacrylamide gel and detected with autoradiography revealed a single band distinct from control sera at $\sim 24,000$ daltons. $^{2}$

\section{DISCUSSION}

Monoclonal antibody A1D2 binds to both normal rat islet cells and RIN islet tumor cells but does not react with rat fibroblasts, GH3 pituitary tumor cells, rat pancreatic acinar cells, or rat spleen cells. In the presence of complement it is cytotoxic to alpha, beta, and delta cells of normal rats and RINm5F tumor cells.

We have previously characterized a number of monoclonal antibodies to the RIN cell line (7). Antibodies $1 \mathrm{G} 3,6 \mathrm{H} 6$, and $5 \mathrm{~B} 5$ bind to both RINm clone $5 \mathrm{~F}$ and RINm clone 14B cells, but do not bind to normal rat islet cells. Antibody 6B2 binds to an antigen found on all nucleated rat cells studied including the RIN tumor cells, fibroblasts, pancreatic islet and acinar cells. Antigen 5D6 is found on RIN cells, normal islet cells, and rat fibroblasts but is not detected on rat acinar cells by indirect immunofluorescence. All of the above monoclonal antibodies bind to antigens that are either tumor "specific" or are expressed on nonislet cells. Antibody A1D2 is the first monoclonal antibody we have produced following immunization with RIN cells that binds specifically to normal islet cells. The only other monoclonal antibody to islet cells that selectively binds to islet cells and does not react with fibroblasts or acinar cells is monoclonal antibody A2B5 that reacts with GQ gangliosides expressed on the surface of islet cells, RIN cells, neurons, and other amine production, uptake, and decarboxylation (APUD)- or neural crestderived cells (9). Antibody A2B5, like tetanus toxin, which also selectively binds to islet cells $(10,11)$, reacts with complex gangliosides, in contrast to antibody A1D2 that reacts with a glycoprotein.

The antigen reacting with antibody A1D2 that we have termed ICSAn-1 (islet cell surface antigen, 1) by affinity chromatography of $\left[{ }^{3} \mathrm{H}\right]$ leucine-labeled cells and by immunoprecipitation of ${ }^{125}$ I-surface-labeled cells is a protein with a molecular mass of $\sim 24,000$ daltons. The antigen was isolated by its ability to bind to a lentil lectin column (a common property of cell surface glycoprotein antigens) and its specific binding to antibody A1D2. Though both antibodies A2B5 and

\footnotetext{
${ }^{2}$ M. Dobersen. Unpublished observations.
}

FIGURE 3 Indirect immunofluorescence of rat pancreatic cells after incubation with antibody A1D2. Fig. 3A is a phase contrast photomicrograph showing the majority of cells to be large, with vacuolated cytoplasm (acinar cells), compared with the small number of smooth cells of lesser size (islet cells with arrows). Fig. 3B, indirect immunofluorescence of the same field shown in $3 \mathrm{~A}$. 

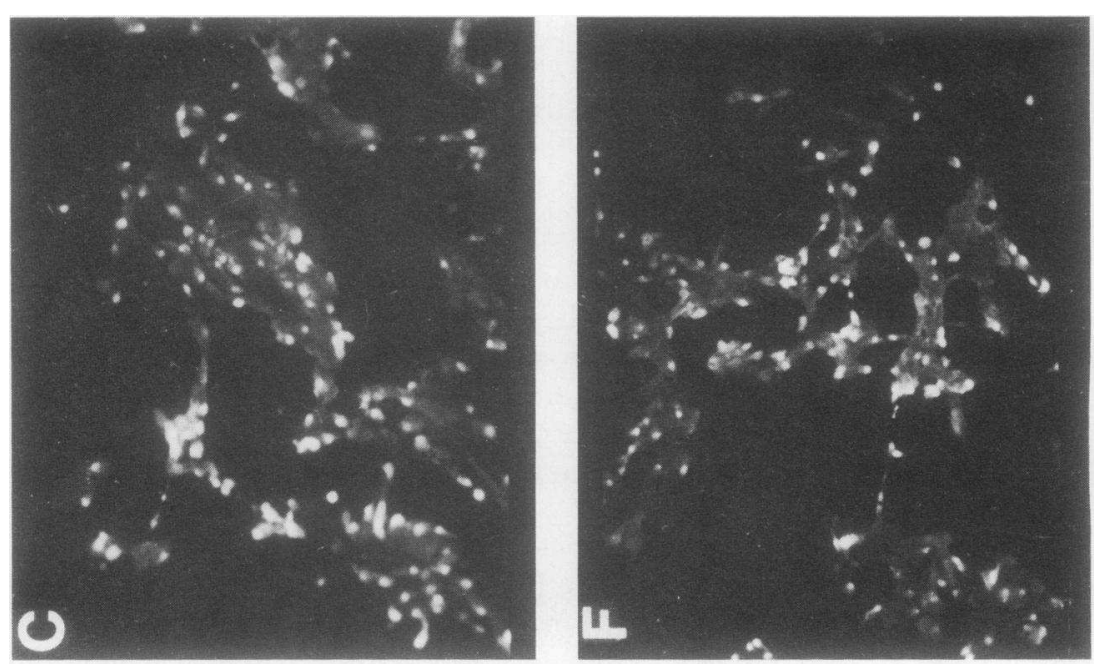

웅옥폭

응

굴

ด䒕

$<00$ 范

ㄱำ ค

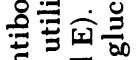

ธี

즐ㅊ웡

苟

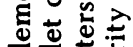

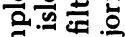

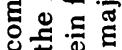

능

응

证可

证

记

屯U

s。

过

E. 융

$\Xi$ घ

훈현

ه.

$\geq \varepsilon$

응

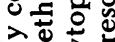

可氙

울

흥하

융응

코

을

हี

은오융

즈ㅇㅝㅛ

굴

II

흘 융

证

20.

今ิ

뜽웡

ฮั

屯

므요

연

녕응

0000 \%

表

동

फ๊

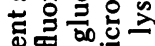

速 है

ฮ

응

压氠造

哈苞范

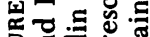

ठำ

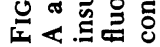




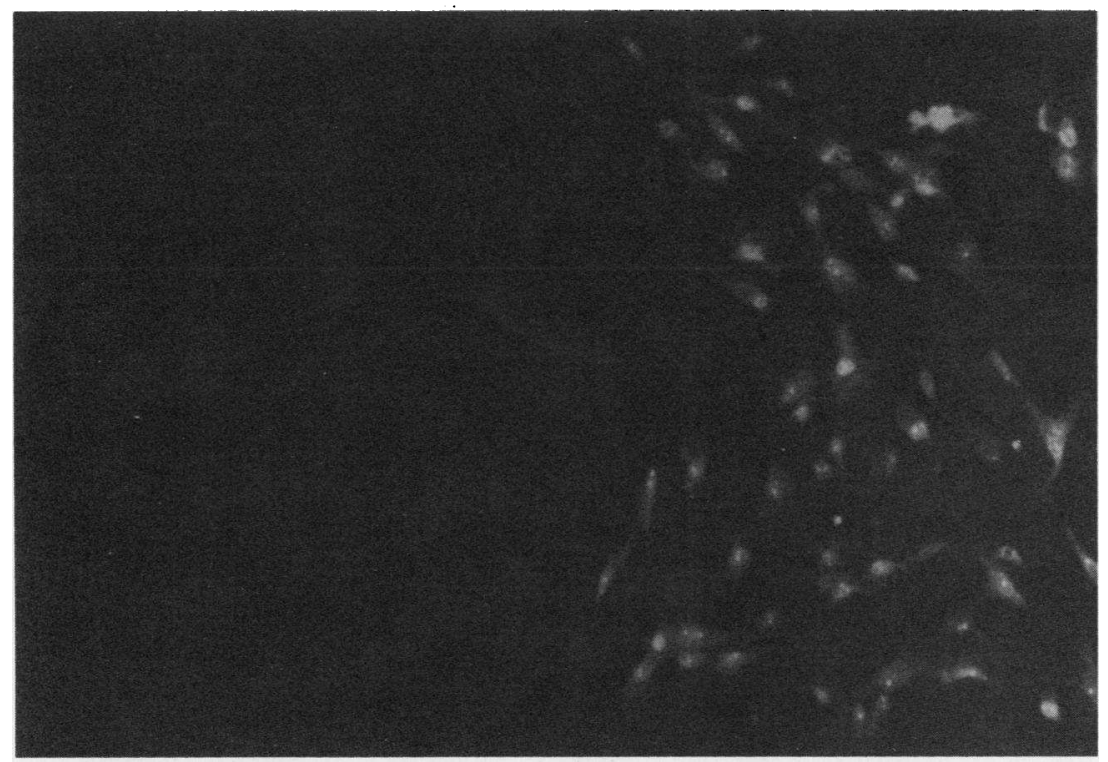

FIgURE 5 Lack of cytotoxicity of antibody A1D2 for rat fibroblasts. Rat fibroblasts were incubated with antibody A1D2 (left side) and unabsorbed human serum (right side) in the presence of complement and ethidium bromide. Ethidium bromide uptake (indicated by fluorescence of nuclei and cytoplasm using a "rhodamine filter") is absent with cells incubated with antibody A1D2.

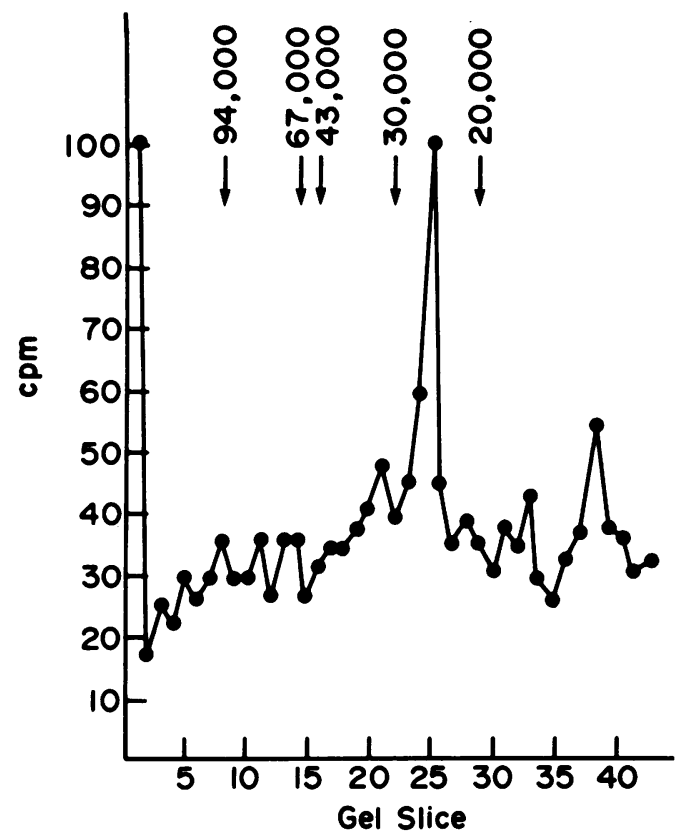

Figure 6 Polyacrylamide gel electrophoresis of affinity purified tritium-labeled (see text) antigen A1D2. Expressed as counts per minute of tritium for 1-mm gel slices. Location of the bands on a companion gel for known molecular weight standards is given by the arrows. The molecular weight of antigen A1D2 is estimated from the peak of counts at gel slice 25.
A1D2 specifically bind to islet cells of pancreatic digests, only antibody A1D2 can be used for the isolation of islet cells using anti-mouse antibody adsorbed to petri plates (Methods). When cells from collagenasedigested rat pancreas or RINm5F cells are incubated with antibody A1D2, washed, and then incubated in a bacterial petri plate containing adsorbed anti-mouse antibody, islet cells selectively adhere to the plate and acinar cells and fibroblasts can be removed by washing the plate. Though the magnitude of antibody A2B5 binding is similar by radioassay to that of A1D2, A2B5coated cells are not bound to plates by adsorbed antimouse antibody. It is not known whether the greater binding of cells to the plate with antibody A1D2 results from its interaction with a glycoprotein antigen (presumably with firmer membrane anchorage) as compared with antibody A2B5 binding to a glycolipid.

Cahill and McDevitt (12) have recently reviewed the autoimmunity hypothesis in the pathogenesis of type I diabetes mellitus. The discovery of antiislet antibodies (reacting with both the cytoplasm and cell surface), "insulitis" at the onset of disease, characteristic histocompatibility leukocyte antigen associations, and the association of type I diabetes with other autoimmune diseases, all strengthen this hypothesis. In addition, major $T$ cell abnormalities are present in the BB Wistar rat model of type I diabetes (13) and in man (14). Furthermore, three different immunologic 
interventions can now prevent the development of diabetes in the BB Wistar rat (15-17) and a single study suggests that immunologic intervention may increase C-peptide excretion $18 \mathrm{mo}$ after the onset of diabetes in man (18). A corollary of the autoimmune hypothesis of type I diabetes is that islet cell, and in particular beta cell specific cell surface antigens, may be the targets of the "autoimmune" process whether it is antibody or cell mediated. The development of a series of monoclonal antibodies to islet cell differentiation antigens should allow the isolation and characterization of relevant antigens. As shown with antibody A1D2, these antibodies will also be useful for the isolation of islet cells and for studies of the effects of pure antibodies on islet cell physiology (19).

\section{ACKNOWLEDGMENTS}

This research was supported by National Institutes of Health grant AM 25778-02 and a Kroc Foundation grant. Dr. Eisenbarth is a recipient of a Basil O'Connor starter grant from the National Foundation-March of Dimes, and a Career Development Award from the Juvenile Diabetes Foundation.

\section{REFERENCES}

1. Lernmark, A., Z. R. Freedman, C. Hofmann, A. H. Rubenstein, D. R. Steiner, R. J. Jackson, R. J. Winter, and H. S. Traisman. 1978. Islet cell surface antibodies in juvenile diabetes mellitus. N. Engl. J. Med. 299: 375380.

2. Eisenbarth, G. S., M. A. Morris, and R. Scearce. 1981. Cytotoxic antibodies to cloned rat islet cells in serum of patients with diabetes mellitus. J. Clin. Invest. 67: 403408.

3. Kohler, G., and C. Milstein. 1975. Continuous cultures of fused cells secreting antibody of predefined specificity. Nature (Lond.). 256: 495-497.

4. Eisenbarth, G. S. 1981. Application of monoclonal antibody techniques to biochemical research. Anal. Biochem. 111: 1-16.

5. Gazdar, A., W. Chick, H. Oie, H. Sims, H. King, G. Weir, and V. Lauris. 1980. Continuous clonal insulin and somatostatin secreting cell lines established from a transplantable rat islet cell tumor. Proc. Natl. Acad. Sci. U.S.A. 77: 3519-3523.

6. Dobersen, M., J. Scharff, and A. Notkins. 1980. Microculture system for studying monolayers of functional Bcells. Endocrinology. 10: 1070-1073.
7. Eisenbarth, G., H. Oie, A. Gazdar, W. Chick, J. Schultz, and R. Scearce. 1981. Production of monoclonal antibodies reacting with rat islet cell membrane antigens. Diabetes. 30: 226-230.

8. Dobersen, M., J. Scharff, F. Ginsberg-Fellner, and A. Notkins. 1980. Cytotoxic autoantibodies to beta cells in the serum of patients with insulin-dependent diabetes mellitus. N. Engl. J. Med. 303: 1493-1498.

9. Eisenbarth, G. S., F. Walsh, and M. Nirenberg. 1979. Monoclonal antibody to plasma membrane antigen of neurons. Proc. Natl. Acad. Sci. U.S.A. 76: 4913-4917.

10. Eisenbarth, G. S., K. Shimizu, M. Conn, R. Mittler, and S. Wells. 1981. Monoclonal antibody F12 A2B5: Reaction with a plasma membrane antigen of vertebrate neurons and peptide secreting endocrine cells. In Monoclonal Antibodies against Neural Antigens. R. McKay, M. Raff, and L. Reichardt, editors. Cold Spring Harbor Symposium. 209-218.

11. Eisenbarth, G. S., K. Shimizu, M. A. Bowring, and S. Wells. 1981. Receptors for tetanus toxin and monoclonal antibody A2B5 on human islet cells and endocrine tumors. Clin. Res. 29: 404

12. Cahill, G. F., and H. O. McDevitt. 1981. Insulin-dependent diabetes mellitus: the initial lesion. N. Engl. J. Med. 304: 1454-1465.

13. Jackson, R., N. Rassi, T. Crump, B. Haynes, and G. S. Eisenbarth. 1981. The BB diabetic rat: profound T-cell lymphocytopenia. Diabetes. 30: 887-889.

14. Jackson, R., M. Bowring, M. Morris, B. Haynes, and G. S. Eisenbarth. 1981. Increased circulating la-positive $\mathrm{T}$ cells in recent onset Graves' disease and insulin-dependent diabetes. 63rd Annual Meeting of Endocrine Society, Cincinnati, OH. 450a.

15. Like, A. A., A. A. Rossini, D. L. Guberski, M. C. Appel, and R. M. Williams. 1979. Spontaneous diabetes mellitus: reversal and prevention in the $B B / W$ rat with antiserum to rat lymphocytes. Science (Wash. DC). 206: 14211423.

16. Like, A. A., R. M. Williams, E. Kislauskis, and A. A. Rossini. 1981. Neonatal thymectomy prevents spontaneous diabetes in biobreeding/Worcester (BB/W) rat. Clin. Res. 29: 542

17. Naji, A., W. K. Silvers, D. Bellgrau, and C. F. Barker. 1981. Spontaneous diabetes in rats: destruction of islets is prevented by immunological tolerance. Science (Wash. DC). 213: 1390-1392.

18. Elliott, R. B., J. R. Crossley, C. C. Berryman, and A. G. James. 1981. Partial preservation of pancreatic $\beta$-cell function in children with diabetes. Lancet. II: 1-4.

19. Rassi, N., G. S. Eisenbarth, and H. E. Lebovitz. 1981. Inhibition of stimulated insulin secretion by monoclonal antibodies to islet cell surface antigens. Clin. Res. 29: 734a. 